same sound material as his writings. For more than a quarter of a century he was a distinctly educative force.

During the War, Coward was acting keeper of the Manchester Museum, and in 1921 the University conferred upon him the degree of M.Sc. in recognition of his services in that capacity. $\mathrm{He}$ was an active member of the Museum Committee, and devoted much time to the arrangement and care of the Dresser collection of birds. He was a member of the executive committee of the Lancashire and Cheshire Fauna Committee, and acted as referee for vertebrates. He was president of the Manchester Literary and Philosophical Society in 1921 and 1922 and a fellow of the Zoological and Entomological Societies.

C. $\mathrm{O}$.

\section{Mr. Henry A. Fleuss}

WE regret to announce the death on January 4 , at the age of eighty-two years, of $\mathrm{Mr}$. Henry Albert Fleuss. He was one of the pioneers of rescue apparatus. After serving in the mercantile service for many years, he left it about 1879 , in order to make a pipeless diving apparatus. He designed a suitable pump for compressing oxygen and made his first test in a tank at the old Polytechnic in Regent St., London. Without any previous experience of diving, he remained under water for one hour, which at that time was an amazing performance.

Fleuss claimed to be the first man to breathe pure oxygen without any ill-effects. At the request of Sir B. W. Richardson, he went into a chamber filled with a gas that meant death in one minute if inhaled, and stayed in there for half an hour. Later, during a lecture given by Sir B. W. Richardson, Fleuss remained in a chamber through which a current of carbon dioxide was made to flow.

Fleuss then turned his attention to mine rescue apparatus and carried out experiments at the Netherseal Colliery and Seaham Colliery. His next exploit was during the building of the Severn Tunnel, the workings of which became flooded. Fleuss went down a shaft $200 \mathrm{ft}$. deep with $40 \mathrm{ft}$. of water at the bottom, and was given up for dead a long time before he returned to the surface. The celebrated diver Lambert then put on the dress and was able to close the necessary doors to enable the tunnel to be pumped out. Messrs. Siebe, Gorman and Co., Ltd., afterwards put the apparatus on the market.

Among Fleuss's other inventions was the wellknown 'Geryk' vacuum pump. He claimed to be the inventor of the first mechanical high efficiency vacuum pump ever made, in 1885 . About $\mathbf{1 8 9 0}$ at a demonstration at the Royal Institution an electric lamp bulb was exhausted with a 'Geryk' pump, and the lamp burned for about 1,000 hours.

Fleuss also invented a tubeless pneumatic tyre which was in great demand about thirty-five years ago.

\section{Dr. Willy Merck}

WE regret to learn from the Chemiker-Zeitung of the death on December 15 of Dr. Willy Merck, a member of the well-known firm of chemical manufacturers, E. Merck of Darmstadt. Dr. Merck, who was born in 1860 at Darmstadt, was the son of Dr. Georg Franz Merck, the discoverer of papaverine. After studying at the Universities of Heidelberg, Strasbourg and Kiel and at the Polytechnic at Aachen, he graduated at Kiel in 1886, where he had worked under the direction of Ladenburg. His thesis embodied the results of his studies on cocaine and he had been able to effect a partial synthesis of this alkaloid by the methylation of benzoylecgonin, a by-product obtained during the extraction of cocaine. Many years later, the complete synthesis of naturally occurring $l$-cocaine and of $d$-pseudococaine was carried out in the Merck laboratories by W. Merck in collaboration with $\mathrm{R}$. Willstätter.

Immediately after his graduation, Merck entered the service of the firm and, after a year's travel in the Far East, he returned to Darmstadt to undertake a leading part in directing the work not only in the laboratories but also in the factory, where he successfully initiated the manufacture of many new drugs. In 1905 the University of Halle conferred upon him an honorary doctorate in the Faculty of Medicine and he was the recipient of many public honours and decorations. He was made Geheimer Kommerzienrat in 1918 on the occasion of the two hundred and fiftieth anniversary of the foundation of the firm.

THE death on February 5 is announced of Mr. J. J. F.-X. King, aged seventy-seven years, one of the best-known Scottish entomologists. Mr. King was an accomplished field naturalist and collector, and some few years ago he presented his main collection of British insects to the University of Glasgow. The University is now to receive under his will the portrait of $\mathrm{Mr}$. King painted by Forrester Wilson and the remainder of his collections, together with his library of books on natural history.

WE regret to announce the following deaths :

Dr. C. A. Barber, C.I.E., lately lecturer in tropical agriculture at the University of Cambridge, formerly Government Botanist, Madras and Sugar Cane Expert for India, on February 24, aged seventy-two years.

Sir Benjamin Gott, chairman of the Commission on Educational and Cultural Films, who was secretary of the Middlesex Education Committee from 1898 until 1928, and formerly headmaster of the Cheltenham School of Science, aged sixtyseven years.

Prof. Johannes Schmidt, director of the Carlsberg Physiological Laboratory, Copenhagen, a leader of several deep-sea expeditions, and known especially for his work on the life-history of the eel, aged fifty-five years. 